\title{
Strategies for managing complex social-ecological systems in the face of uncertainty: examples from South Africa and beyond
}

\author{
$\underline{\text { Reinette (Oonsie) Biggs }}^{1,2,3}$, Clint Rhode ${ }^{4}$, Sally Archibald ${ }^{5,6}$, Lucky Makhosini Kunene $^{7,8}$, Shingirirai S. Mutanga ${ }^{8}$, Nghamula \\ Nkuna $^{9}, \underline{\text { Peter Omondi Ocholla }}^{10,11}$ and Lehlohonolo Joe Phadima ${ }^{12}$
}

\begin{abstract}
Improving our ability to manage complex, rapidly changing social-ecological systems is one of the defining challenges of the 21 st century. This is particularly crucial if large-scale poverty alleviation is to be secured without undermining the capacity of the environment to support future generations. To address this challenge, strategies that enable judicious management of socialecological systems in the face of substantive uncertainty are needed. Several such strategies are emerging from the developing body of work on complexity and resilience. We identify and discuss four strategies, providing practical examples of how each strategy has been applied in innovative ways to manage turbulent social-ecological change in South Africa and the broader region: (1) employ adaptive management or comanagement, (2) engage and integrate different perspectives, (3) facilitate self-organization, and (4) set safe boundaries to avoid system thresholds. Through these examples we aim to contribute a basis for further theoretical development, new teaching examples, and inspiration for developing innovative new management strategies in other regions that can help address the considerable sustainability challenges facing society globally.
\end{abstract}

Key Words: adaptive management; complexity; resilience; social-ecological systems, southern Africa; uncertainty

\section{INTRODUCTION}

Humanity faces a defining challenge in the 21 st century: to reduce poverty and inequality in the face of a rapidly growing world population, without undermining the capacity of the Earth to meet the needs of current and future generations (MA 2005, Martin 2007, Biggs et al. 2012a, Griggs et al. 2013). Given the interconnectedness of global social, economic, and ecological systems, it is increasingly acknowledged that addressing this challenge requires an integrated approach that accounts for the multiple interlinkages and dependencies between social and ecological systems (Berkes et al. 2003, Chapin et al. 2009). At the same time the rapid pace at which these interconnected systems are changing, often in entirely novel ways, requires governance and management strategies that are robust to uncertainty about system dynamics and how these might change into the future (Levin et al. 2013, Biggs et al. 2015). Addressing these challenges requires new and expanded frameworks and approaches for understanding the world in which we live and informing policy and practice (Bammer 2005, Allenby and Sarewitz 2011, Cilliers et al. 2013).

One theoretical framework that is drawing increasing attention as a useful way to understand the intertwined social and ecological challenges we face and how we might address these is complex systems theory (Cilliers 1998, Gros 2008). In this framework, interactive systems of people and society, or social-ecological systems (SES), are seen as complex adaptive systems (Holling 2001, Norberg and Cumming 2008). Such systems comprise a large number of entities that display a high level of dynamic interaction and emergent behavior. The nature of SES as complex adaptive systems has profound implications for how we do our research (Audouin et al. 2013), the possibility to understand SES dynamics (Levin et al. 2013, Cilliers et al. 2013), and how we seek to govern and manage SES (Young 2010, Biggs et al. 2015). In this paper we do not discuss the full ambit of these implications, but focus specifically on dealing with one key feature of SES: inherent uncertainty.

Uncertainty is an integral feature of complex adaptive systems and in SES arises from several sources. First, SES are selforganizing and continuously evolve and change in response to external shocks and internal system changes (Gunderson and Holling 2002, Levin et al. 2013). This means that understanding the dynamics and interactions within an SES is at least partly a moving target, and managing SES requires continual learning and adaptation of management strategies (Armitage et al. 2009, Biggs et al. 2012b). Second, uncertainty arises from interactions between the components of the system, e.g. trees, people, that give rise to emergent SES properties, especially nonlinear behavior that cannot be predicted from knowledge of the individual system parts (Holland 1999). A third source of uncertainty stems from societal values, which play a critical role in deciding on desired social and ecological outcomes, resolving trade-offs, and influencing tolerance for risk and uncertainty (Cortner and Moote 1999, Bocking 2004). Differences in values among different societal groups and changes in values over time create substantial uncertainties about which management strategies best meet societal goals.

These three sources of uncertainty give rise to three types of complexity (Mollinga 2010). Analytical complexity arises from the difficulty of understanding complex systems, both because the system itself is complex and because knowledge of the overall

${ }^{1}$ Stockholm Resilience Centre, Stockholm University, Sweden, ${ }^{2}$ Stellenbosch Institute for Advanced Study (STIAS), Wallenberg Research Centre at Stellenbosch University, South Africa, ${ }^{3}$ Centre for Studies in Complexity, Stellenbosch University, South Africa, ${ }^{4}$ Department of Genetics, Stellenbosch University, South Africa, ${ }^{5}$ Natural Resources and the Environment, CSIR, South Africa, ${ }^{6}$ Centre for African Ecology, Animal Plant and Environmental Sciences, University of the Witwatersrand, South Africa, ${ }^{7}$ Department of Sociology, University of Fort Hare, East London, South Africa, ${ }^{8}$ Africa Institute of South Africa, Human Sciences Research Council, South Africa, ${ }^{9}$ Public Administration, University of Limpopo, South Africa, ${ }^{10}$ Department of Earth Sciences, Stellenbosch University, South Africa, ${ }^{11}$ Department of Hydrology, University of Zululand, KwaDlangezwa, South Africa, ${ }^{12}$ Scientific Services Division, Ezemvelo KwaZulu-Natal Wildlife, South Africa 
behavior of the system is always partial. Ontological complexity arises from the unpredictable (nonlinear) behavior of complex systems. Societal complexity arises from the different meanings, benefits, and purposes that different societal groups attach to SES.

Acknowledging these different aspects of complexity is crucial to developing strategies for living in and managing SES. There is growing acknowledgement that managing complex SES requires approaches that go beyond a focus on informing management through improved understanding of system components and dynamics, and facilitate judicious management in the face of substantial uncertainty and potential risks (Stafford Smith et al. 2011, Biggs et al. 2015). Inherent uncertainty in SES is a key contributor to so-called "wicked problems," of which the sustainability challenges society faces are a prime example. Wicked problems typically involve situations of substantial, ongoing change, major systemic uncertainties, disputed facts and values, contradictory, changing needs, and often require urgent, high-stakes decisions (Funtowicz et al. 1999). Such problems are usually expressed at the larger system level, rather than at the system component level (Allenby and Sarewitz 2011), and complex interdependencies mean that efforts to solve one aspect of a wicked problem often reveals or creates other problems (Holling and Meffe 1996). Consequently there are no "silver bullets" for solving wicked problems; instead, addressing wicked problems requires decision making in the face of substantial uncertainty and combining multiple strategies that need to be constantly adjusted and adapted over time in an attempt to foster sustainable trajectories of change (Ostrom et al. 2007, Young 2010).

In this paper, we identify and discuss four complexity-based strategies for managing SES in the face of substantial uncertainty and change. These strategies draw especially on resilience theory, an approach that seeks to apply complex systems theory to issues of social-ecological sustainability (Norberg and Cumming 2008, Biggs et al. 2015). We provide examples of how each strategy has been applied in innovative ways to manage turbulent, changing SES in South Africa and the broader southern and East African region. This is one of the most biodiverse regions on Earth, but poverty levels are high, populations are growing rapidly, and human capacity to manage fast-changing, globally connected societies is often extremely limited (UNDP 2013). By contributing examples of how complexity-based strategies have been applied to manage complex SES in this challenging developing region context, we aim to provide new teaching examples, a basis for further theoretical development, and inspiration for the development of innovative SES management strategies in other regions.

\section{STRATEGIES FOR MANAGING SES IN THE FACE OF UNCERTAINTY}

A variety of new approaches to dealing with ongoing change and uncertainty in SES are emerging, motivated by the pressing sustainability challenges facing society and informed by a growing body of theoretical and empirical work on SES (Kates et al. 2001, Folke et al. 2010, Biggs et al. 2015). To reflect on approaches that are particularly relevant in the southern African region, we ran two workshops involving 25 young scientists from the region as part of the Akili Complexity and Integration Initiative. The Akili
Young Scientists (AYS) were selected based on their track record, experience, and enthusiasm to learn about complexity and resilience theory and how it might be applied to address pressing regional challenges. The AYS came from a diverse set of backgrounds, i.e., genetics, ecology, political science, public administration, and in addition to having at least a Master's degree, many had worked in the public and private sector. A subset of this group (the authors of this paper) focused on identifying complexity-based strategies for managing SES in the face of uncertainty, drawing especially on the body of work associated with the resilience approach (Gunderson and Holling 2002, Berkes et al. 2003, Walker and Salt 2006, 2012, Westley et al. 2006, Armitage et al. 2007, Ostrom 2007, Norberg and Cumming 2008, Chapin et al. 2009, Biggs et al. 2015).

Based on a review of the literature, the authors' personal experience of particular cases in the region, and feedback from senior scientists in the Akili network we identified four strategies and a series of examples that have been applied to manage SES in the southern African region in the face of substantive uncertainty: (1) employ adaptive management or comanagement; (2) engage and integrate different perspectives; (3) facilitate selforganization; (4) set safe boundaries to avoid system thresholds. We do not suggest these are the only possible strategies for managing SES, but they appeared to be particularly relevant in the southern African context. Figure 1 provides an overview of the different strategies and examples, illustrating the main types of complexity addressed by each strategy, and the specific approaches or tools used in each example.

A few final points before introducing the strategies. The four strategies are interrelated and typically used in combination in actual SES management; most of the examples we describe contain elements of several strategies. In discussing the examples, we have linked them to the strategy they illustrate most clearly, where the strategy has been applied in an innovative way, or where an illustrative pitfall has been encountered. We do not provide a complete analysis of the examples, which is available in the supporting literature, but rather highlight specific aspects of the strategy that are illustrated by the particular case. The cases are based on examples with which the authors are familiar or for which there was substantial published literature. Because most of the authors are from South Africa, many of the examples are from this country and, as a set, are not intended to be representative of the region. Furthermore, given the small sample size and the approach we have used, the examples cannot be taken as proof of the effectiveness of the different strategies, which would require more detailed comparative studies. Last, numbering of the strategies is purely for convenience and does not reflect the relative importance of the different strategies.

Strategy 1: employ adaptive management or comanagement The core concept in adaptive management is to treat ongoing management actions as deliberate, large-scale experiments. The approach arose in the natural sciences and was originally conceptualized as a way of combining ongoing management actions with research on ecosystem dynamics, i.e., to "learn while doing" (Holling 1978, Walters 1986). Adaptive management builds on experimental research approaches but acknowledges that plot and field scale experiments seldom capture the scales needed to understand ecosystems, while large-scale scientific 
Fig. 1. Overview of the four strategies and their respective examples discussed in this paper, showing the main type of complexity addressed by each strategy (top), and the main tool or approach used in each of the examples (bottom). Note that all strategies to some degree address all three types of complexity, and most examples contain elements of several strategies; the figure indicates only the main aspects as discussed in the paper.

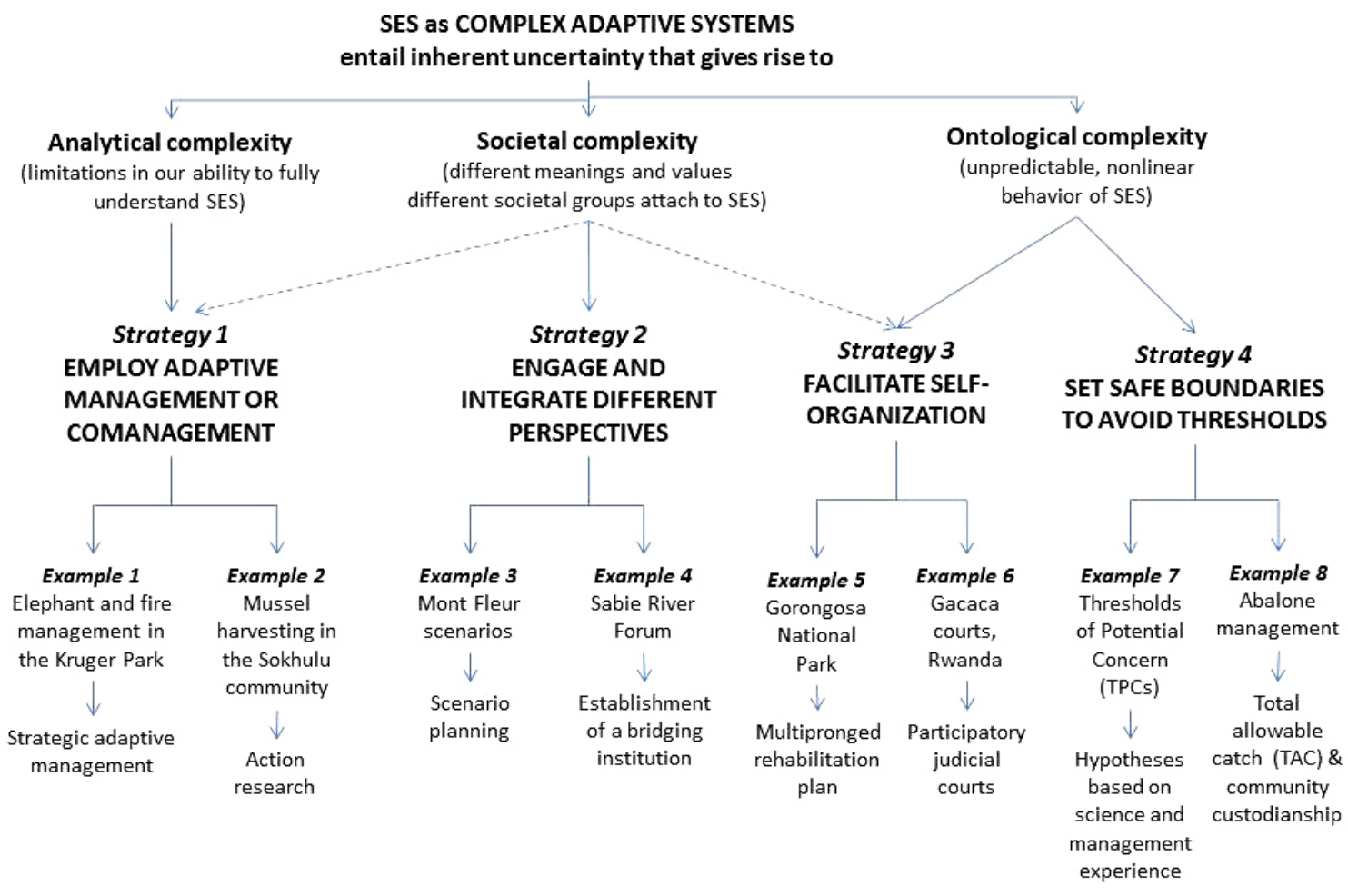

experiments are usually infeasible. Operationally, the approach involves the formulation of explicit hypotheses about SES dynamics and the potential outcomes of different management actions. These alternative hypotheses are tested by implementing different management strategies in clear, consistent ways that enables differences among strategies to be identified. Monitoring and comparing the outcomes of different management actions is therefore central (Walters and Holling 1990, Allan and Stankey 2009).

In implementing adaptive management, it has become clear that substantial attention needs to be paid to processes of social learning and engaging stakeholders (Lee 1993). This realization has given rise to adaptive comanagement, an approach that combines the iterative learning dimension of adaptive management with participatory processes of collaborative management where rights and responsibilities are shared (Armitage et al. 2007, RA 2007). Adaptive comanagement retains a focus on learning while doing, often achieved through an action research approach. Action research was developed in the social sciences and aims to gain knowledge of a system in a way that facilitates social learning, while actively committing to a course of action and bringing about system change (Burns 2007, Reason and Bradbury 2007). Stakeholders are actively engaged in the process, including the researcher, who is seen as a participating member of the system rather than an objective observer. Although action research does not entail the explicit formulation of alternative hypotheses, similar to adaptive management, it enables problem solving and continued knowledge creation through iterative cycles of data collection, reflection, planning, and action that critically evaluate how the system reacts to various actions (McKay and Marshall 2001). To illustrate how this strategy has been applied to manage uncertainty in SES in southern Africa we present two examples: one focusing on the use of adaptive management in one of South Africa's premier national parks, and the second illustrating how an action research process has been applied within an adaptive comanagement setting to facilitate learning.

Elephant and fire management in the Kruger Park, South Africa Elephant and fire management in the Kruger National Park have always been contentious issues. Experience in other African parks suggests that, if unconstrained, elephant numbers will increase to a level where they dramatically alter vegetation and associated ecosystem structure and function, threatening the survival of other species (Scholes and Mennell 2008). However, culling of elephants raises major ethical concerns and has led to proposed tourism boycotts with major implications for the financial viability of the park system. Similarly, preserving the fire-adapted savanna ecosystems of the Kruger Park requires specific types of fires, such as high-intensity fires at hot and dry times of the year, but these fires threaten the safety of people living in and adjacent 
to the park (van Wilgen et al. 2011). Further complicating the situation is the fact that the impacts of elephants are difficult to disentangle from the effects of fire (Scholes and Mennell 2008).

Historically, elephant and fire management focused on maintaining specific elephant numbers and particular fire patterns in the park. Elephants were maintained at a constant level of about 7500 animals irrespective of year-to-year environmental variability (Scholes and Mennell 2008), while fire was managed by dividing the park into blocks, with each block burnt at a particular frequency and season (van Wilgen et al. 2000). These management policies were largely disconnected from ongoing research, which focused on elephant population and foraging biology, and small-scale fire plot experiments. Learning in this approach was very slow because many important management questions could not be answered by the scale of research being conducted, and there was no formal process for informing and adapting management as information became available from research (Biggs and Rogers 2003).

Influenced by emerging literature, adaptive management approaches were adopted in the Kruger Park in the 1990s and landscape-scale management strategies started being conceptualized as potential "learning experiments" (Biggs and Rogers 2003, van Wilgen et al. 2011). The park proposed creating low and high elephant density areas that cut across the major geology and rainfall zones in the park to better understand landscape scale impacts of fire and elephants. This setup would provide an opportunity to investigate the assertion that elephants exponentially increase the damage caused by fire. More fundamentally, the approach will enable examination of the landscape-scale impacts of different elephant densities. Elephant numbers have never been allowed to increase in an unconstrained way since the inception of the park, so there is no actual empirical evidence of the impact of high elephant numbers, a major weakness in defending the park's policies to animal rights groups (Scholes and Mennell 2008). Various logistical and political factors have impeded the implementation of the proposal to date, but there remains a strong interest in operationalizing it in some form to better inform management objectives and policies in the park.

A key feature of the transition to adaptive management in the Kruger Park was a strong emphasis on improving the flow of information between scientists and managers. This was achieved through the implementation of a locally adapted version of adaptive management, called Strategic Adaptive Management (SAM; Fig 2; Biggs and Rogers 2003). SAM differs from conventional adaptive management in placing substantial emphasis on proactive modes of decision making. This is supported by a strong goal-setting component, which in the case of the Kruger Park involved developing a detailed hierarchy of objectives for the park together with well-articulated monitoring endpoints called Thresholds of Potential Concern (TPC) (see strategy 4). Together, the objectives hierarchy and TPCs connect science, monitoring, and management to facilitate structured colearning between research and management (Biggs and Rogers 2003). A recent evaluation of SAM suggests that the process has prompted a substantial amount of experimentation and learning (Roux and Foxcroft 2011), and despite challenges that have arisen in operationalizing the TPCs, the approach has proven practical in many contexts and has revolutionized the management philosophy in the park (Biggs et al. 2011). In particular, it has shifted thinking away from managing for fixed targets, e.g., 7500 elephants, to managing for a range of variation, focusing on landscape-scale impacts and outcomes.

Fig. 2. Schematic summary of the steps in the strategic adaptive management process. From Roux and Foxcroft (2011).

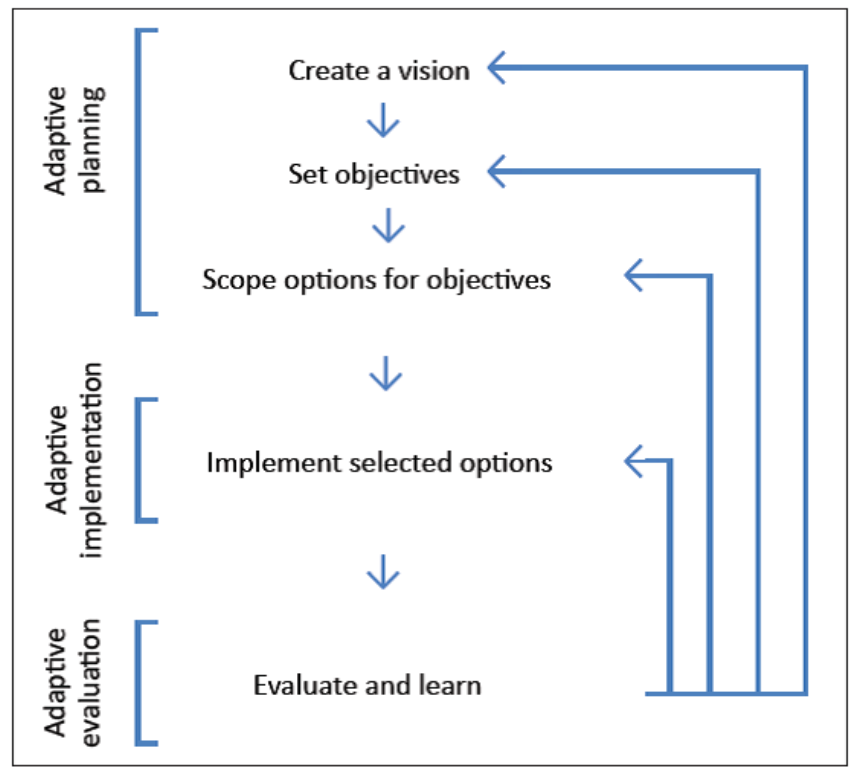

This example illustrates how adaptive management can provide a strategy for generating better scientific understanding about large-scale social-ecological processes, while enabling management to proceed in the face of uncertainty about these processes. At the same time, the difficulties in practically implementing the proposed ideas highlight the challenges with operationalizing adaptive management approaches. Nevertheless, the discussions generated by the proposal and the way in which adaptive management has been implemented in Kruger has provided a mechanism for scientists and managers to interact more closely and learn from one another, which has also helped build the social capital and trust needed to facilitate decision making in the face of uncertainty (see strategy 2).

\section{Mussel harvesting in the Sokhulu community, South Africa}

Sustainable harvesting of mussels is a key challenge in the coastal belt of KwaZulu-Natal, South Africa (Fig 3). Major socioeconomic challenges face local communities, including unemployment, poverty, and low levels of education; consequently they are substantially dependent on mussels for their nutrition and livelihoods. By the 1990s, growing demand had created a serious threat to the mussels and the livelihoods of coastal communities. Human population growth combined with a breakdown of traditional norms and values led to an increasing number of harvesters who did not follow traditional rotational mussel harvesting methods (UNEP 2006). In addition, some harvesters started harvesting for sale rather than subsistence. These changes were aggravated by the transition to democracy in South Africa in 1994, which increased the sense of entitlement 
among the poor, especially their right to resource use without governmental restriction. These social changes were compounded by biological changes in the mussel population associated with changing climate conditions (Harris et al. 2003).

Fig. 3. Gathering mussels along the KwaZulu-Natal coast. Photo credit: J Phadima.

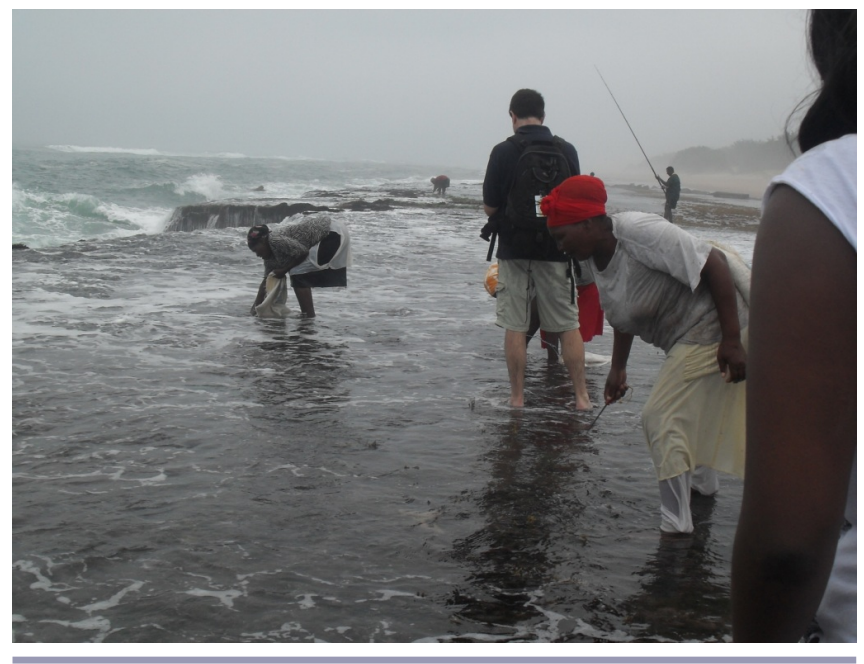

To protect the dwindling mussel resource, the provincial conservation agency, Ezemvelo KwaZulu-Natal Wildlife (EKZNW), instituted a permitting system that aimed to substantially decrease harvest levels. However, it soon became clear that law enforcement activities were simply driving the harvesting underground and had deprived the community of an essential source of protein (UNDP, UNEP, WB, and WRI 2003). In addition, it exacerbated the use of inappropriate harvesting methods; villagers started collecting mussels at night, completely stripping rocks with coarse tools to work fast and avoid detection and arrest (Harris et al. 2003, UNEP 2006).

Acknowledging the failure of the permitting approach, EKZNW engaged in an action research process to investigate alternative ways of protecting the mussels. Working together with researchers and a community liaison officer, EKZNW engaged women from the community to develop harvesting approaches based on traditional methods. These methods relied on a system of rotational harvesting that allowed each mussel bed to recover for several years, and during especially vulnerable times closed harvesting completely. Experiments were set up together with the community to determine sustainable harvest levels. Seeing the results of their experiments, the community agreed to the limits set for the new harvesting system (UNEP 2006). Community monitors were appointed and trained to record data about quantities harvested, localities, and number of harvesters, and were tasked with ensuring that only approved harvesting implements were used (Harris et al. 2003).

The new participatory mussel conservation approach proved highly successful and formed the basis for a comanagement agreement between EKZNW and the Sokhulu community in 1995 (Harris et al. 2003). The success of the project has been extended to other communities and EKZNW now oversees 17 comanagement committees involving 11 fishing communities, and 1168 people who sustainably harvest some 16,700 tons of food annually from KwaZulu-Natal coast (UNDP, UNEP, WB, and WRI 2003). This example illustrates how well-implemented collaborative processes can help identify effective management strategies that meet multiple objectives (mussel conservation, local livelihoods) among diverse stakeholders while respecting local knowledge, culture, and history.

\section{Strategy 2: engage and integrate different perspectives}

The complexity of SES means that any actor has only a partial understanding of the system (Cilliers et al. 2013). Theoretical and empirical studies have shown that SES can be better understood (Alcamo 2001), uncertainty better gauged (Biggs et al. 2009, Swart et al. 2009), and problem solving enhanced (Hong and Page 2004 ) by bringing a diversity of perspectives to bear on a problem. In addition, engaging stakeholders with different perspectives and interests is central to developing trust, facilitating learning, and developing a more widely shared understanding of management problems and the systems in which they are embedded. Provided the process of engaging different stakeholders is well managed, these factors substantially increase the probability of reaching and implementing management decisions in the face of uncertainty (Armitage et al. 2007, Biggs et al. 2012b).

However, bringing together practitioners and scientists from the diverse fields needed to address the multifaceted challenges of SES is a challenging task (Bocking 2004, Bammer 2005). One key issue is that social and natural science are to some extent embedded in fundamentally different world views (Parsons 2003). Natural science assumes a realist belief that science is a process of discovering the truth about an objective reality. In contrast, much of the social sciences are based on a constructivist belief that scientific findings depend on the questions asked, so that all knowledge is socially constructed and context dependent. Furthermore, the scientific process, methods, and meaning of uncertainty may be poorly understood and mistrusted by practitioners, nonacademic stakeholders, and the wider public (Brugnach et al. 2007).

A growing body of work suggests that identifying common goals and visions, building trust, and facilitating meaningful interaction between parties are key to successful transdisciplinary problemsolving in the face of uncertainty (Armitage et al. 2007, Leach et al. 2015). A variety of tools and institutional processes can facilitate this process. Participatory scenario planning is one powerful approach for bringing together different stakeholders to consider the dynamics of a system and its potential future trajectories (Peterson et al. 2003). It can be remarkably effective in broadening understanding of complex SES and associated system uncertainties (Kahane 2004, Biggs et al. 2010a). More generally, institutional structures that facilitate the engagement and integration of different stakeholders and perspectives can provide powerful ways of engaging with uncertainty, and building trust and shared understanding (Wondolleck and Yaffee 2000, Ostrom 2005). Below we provide an example of how scenario planning and innovative institutional structures have been used in powerful ways to manage situations of high complexity and uncertainty.

Mont Fleur scenarios, South Africa

South Africa in the late 1980s faced a situation of radical uncertainty as it became clear that the Apartheid regime and its 
policy of racial discrimination were no longer tenable. However, it was exceedingly unclear how a transition to full democracy could be effected without massive societal upheaval, and many believed that substantial bloodshed and violence were unavoidable (Clark and Worger 2011). The Mont Fleur scenario exercise was undertaken in 1991-1992 to discuss and explore different ways in which the transition to democracy might take place and what the consequences of different pathways might be. The exercise brought together 22 influential South Africans from the black and white communities, and has been hailed as a key initiative that helped change mindsets and pave the way for a peaceful political transition in 1994 (Kahane 1992, Kahane 2004).

The scenario team met in a series of workshops at the Mont Fleur conference center outside Cape Town to share ideas and debate the country's future (Kahane 1992). After considering many possible scenarios, the participants agreed on four they believed most relevant: (i) ostrich, in which a negotiated settlement to the political crisis in South Africa is not achieved and minority rule continues, (ii) lame duck, in which a coalition government is formed but is weak and incapacitated by restrictions so that the transition is slow and indecisive, (iii) Icarus, in which a rapid transition occurs, but the new government pursues unsustainable populist economic policies leading to an economic crisis, and (iv) flight of the flamingos, a positive outcome where a negotiated settlement and sound governmental policies put the country on a path of inclusive growth and democracy (Kahane 2010).

The scenario process is credited with contributing to the formal negotiations and a successful political transition in South Africa in both direct and indirect ways. The scenarios themselves each contained a clear and substantive message about the options that faced South Africa at the time, and potential traps such as excessive spending, or insufficient change (Peterson et al. 2003). Perhaps more importantly, the process resulted in a shift in mindsets among the participants. Many of the participants had come into the process with very different views of the desired future for the country, and not expecting that they would be able to agree on anything (Kahane 2004). However, all participants came into the process willing to engage in discussion. The process was facilitated by a skilled group of international experts, and by the end of the scenario exercise the participants had come to an agreement that the only viable way forward was a flight of the flamingos type scenario (Kahane 2010). This coming together of participants' views had a direct bearing on the formal negotiation process that was occurring simultaneously, with at least one political party substantially revising its approach to the negotiations (Kahane 1992). In addition, the scenario development process created mutual understanding and friendships among a diverse group of influential South Africans from across the political spectrum, which has also been credited with contributing to the success of the formal negotiation process (Kahane 2004).

This example is a particularly powerful illustration of how a wellfacilitated process can help build the common understanding and trust needed to take complex societal decisions in the face of substantial uncertainty about the future. By focusing on the future rather than the present, scenario planning can help highlight points of agreement and consensus among stakeholders, and create a space for discussing points of disagreement, underlying assumptions, and alternative options in an open way (Kahane 2004, Kahane 2010).

\section{Sabie River forum, South Africa}

The Sabie River is a perennial river in eastern South Africa, and is regarded as one of the country's flagship rivers because of its high aquatic diversity and relatively unimpacted ecological condition (CSIR 2001). However, upstream extractive uses of the river compete directly with downstream subsistence, tourism, and conservation needs; the upper catchment is under commercial timber plantations, whereas the lower reaches fall within the Kruger National Park. The central region supports commercial irrigated agriculture as well as providing domestic water for impoverished rural communities living adjacent to the Park (O’Keeffe and Rogers 2003).

These competing uses came to a head in March 1992 when a major drought combined with increased commercial withdrawals brought the river to a trickle, and it was projected to run completely dry by July/August 1992 for the first time in recorded history (Venter and Deacon 1995). Given the high biodiversity value of the Sabie River, this situation was of significant concern to scientists in the Kruger Park. The situation was also of grave concern to irrigation farmers and domestic water users in the central reaches of the river who depended on the water for their livelihoods. Prompted by this situation, the Kruger scientists called a meeting with the Sabie River Irrigation Board. The discussions resulted in the formation of a task team to investigate options for addressing concerns surrounding the drought, and subsequent stakeholder meetings led to the formation of the Sabie River Working Group (SRWG; Biggs et al. 2010b).

The SRWG included representatives from all the key stakeholder groups in the catchment, and acted as a bridging organization that provided a platform for promoting dialog and agreeing on a joint set of goals and actions. Despite initial antagonism between especially the forestry and irrigation sectors, the group was able to agree on a common vision: to prevent the Sabie River running dry, and ensure fair distribution of the limited water supply (Biggs et al. 2010b). Through the development of a "team spirit" fostered by social activities such as field trips and barbeques, the different stakeholders were motivated to propose and carry out activities to realize these goals. For example, the irrigators voluntarily developed and implemented water restrictions, while the forestry sector volunteered to remove runaway alien trees in the upper catchment to improve water flow (O'Keeffe and Rogers 2003). The voluntary actions of the stakeholders enabled the SRWG to meet its objectives, and the river never stopped flowing during the drought.

The SRWG remained active as a coordinator and facilitator of activities in the Sabie River Catchment for about a decade after its formation. The group was eventually disbanded during attempts to establish the Inkomati Catchment Management Agency, a government-initiated agency mandated by legislation that aims to fulfill similar functions to the SRWG. The legislation mandating the establishment of catchment management agencies across all major catchments in South Africa is widely heralded as visionary (Postel and Richter 2003, Gowlland-Gualtieri 2010) because it is based on contemporary understanding of complex systems and aims for high levels of stakeholder participation and 
empowerment. However, implementation of this legislation has been highly problematic, partly because of the command-andcontrol culture of the Department of Water Affairs, and serious capacity constraints (Rogers et al. 2000, Herrfahrdt-Pähle 2010).

This example illustrates how institutional structures such as forums or working groups can provide a powerful mechanism for engaging different stakeholders, building trust and shared understanding of a system, and facilitating agreement and management action in the face of conflicting demands, uncertainty, and change (Biggs et al. 2010a). At the same time, the example warns of the potential for enhancing conflict and antagonism if such structures are poorly implemented and dysfunctional, and there is not a sense of ownership among stakeholders.

\section{Strategy 3: facilitate self-organization}

Complex adaptive systems such as SES are self-organizing systems; they can adjust and reorganize autonomously in response to internal and external changes (Levin et al. 2013, Biggs et al. 2015). Self-organization is a process whereby a structure or pattern appears in a system without a central authority or external element imposing it through planning (Feltz et al. 2006). This selforganizing property arises from the many feedback processes in an SES; changes to any one part of the system lead to changes in other parts of the system that eventually feedback to change the original component. Two types of feedback loops exist (Meadows 2008). Positive or amplifying feedbacks reinforce system effects, for example warming temperatures associated with climate change reduce sea-ice cover, which further enhances climate warming and reduction of sea-ice. In contrast, balancing or negative feedbacks dampen changes in the system. For example, if maize harvests are low, scarcity will drive prices up, which should prompt more farmers to plant maize, and bring the price down again.

In most cases, some set of feedbacks tend to become dominant over time, so that the SES becomes structured and functions in a particular way. Dominant feedbacks are often self-reinforcing, creating conditions that enhance their persistence (Biggs et al. 2012a). However, if a large shock hits the system, or some other factor slowly weakens the dominant feedback processes, SES structure may be eroded to the point where key system components remain only weakly connected (Gunderson and Pritchard 2002). The SES becomes "loose" and unable to respond cohesively or counter the impact of shocks, and the behavior and future trajectory of the system becomes highly uncertain. This situation typifies the $\Omega$-phase of the adaptive cycle (Gunderson and Holling 2002). The SES may remain trapped in this condition forming a so-called Holling poverty trap (Holling 2001), or can reorganize in several different configurations depending on which feedbacks become dominant (see strategy 4). Under these open, unstructured conditions, small differences can have a major impact on the future configuration and development trajectory of the system.

By understanding the nature of feedbacks, SES managers can "work with" systems to facilitate self-organization and bring about change in destructured systems. This involves the identification of leverage points that can promote self-reinforcing change, or the creation of key structures around which the SES can organize and develop in a self-reinforcing way (Meadows
2008, Nyström et al. 2012). We highlight two examples from wartorn regions in southern and East Africa where this strategy has been employed: the first to rebuild wildlife numbers in an iconic regional park, and the second to rebuild social trust. Immediate postwar situations provide extreme examples of destructured systems where facilitating self-organization is a particularly powerful tool for dealing with uncertainty. However, many of the principles of self-organization apply in other contexts, for example in political transitions (see Mont Fleur scenarios under strategy 2) or when local economies transition from subsistence agriculture to ecotourism.

\section{Gorongosa National Park, Mozambique}

Gorongosa National Park is a $4200 \mathrm{~km}^{2}$ conservation area in central Mozambique. At the time of its creation in the 1960s the park supported some of the densest wildlife populations in Africa, with the first aerial survey counting over 200 lions, 2200 elephants, 14,000 buffalo, and 5500 wildebeest (Gorongosa National Park 2015). However, between 1977 and 1993 a violent civil war erupted in Mozambique, in which close to a million people died from fighting and starvation, 5 million civilians were displaced, and many people were made amputees by landmines (Robinson 2006). The Gorongosa area was particularly hard hit, and in 1983 the park was shut down and abandoned. Fierce fighting and aerial bombing destroyed buildings and roads, and the park's wildlife was decimated by hungry soldiers seeking food and ivory to buy arms and supplies (Hatton et al. 2001). By the end of the war surveys counted just 15 buffalo, 5 zebra, 6 lions, 300 elephants, and a handful of wildebeest (Gorongosa National Park 2015).

After the war there was immense uncertainty as to whether and how the park and its wildlife could be restored in this war-ravaged, depopulated, and poverty-ridden region. From 1994 onward foreign donors, i.e., the African Development Bank, European Union, the International Union for Conservation of Nature, and later the Carr foundation, initiated a rehabilitation plan with the support of the Mozambique government, which aimed to promote safety and stability in the region. Although not framed in systems terms, the rehabilitation plan identified three key leverage points and associated rehabilitation strategies aimed at setting in motion reinforcing feedbacks to facilitate selforganizing recovery of the region.

The first strategy focused on rebuilding key infrastructure: the bombed roads and trails. The roads provided access for park managers to carry out crucial management activities and later for tourists to return, thus providing the basis for a reinforcing feedback to help rebuild, develop, and grow the park. The second strategy focused on careful reintroductions of indigenous herbivores and predators into a small secure wildlife sanctuary in the center of the park. This enabled wildlife numbers to start growing, and mitigated the extensive bushmeat trade and subsistence hunting occurring on the park periphery. The third strategy focused on rebuilding the communities surrounding the park, and promoting peace and economic stability in the region. There was a focus on rehiring and promoting people who had previously worked in the park, as well as hiring former soldiers to help reintegrate them into society. Law enforcement adopted a strong community focus, training people and giving them incentives not to poach. In addition, a substantial part of the donor funding went toward schools and health clinics. These 
actions all contributed to setting in motion feedbacks, especially those involving employment and economic opportunities, that put the recovery of the park in the interests of the surrounding community. At the same time they reduced the potential for the development of destructive social feedbacks, e.g. poaching and crime, that could jeopardize the recovery of the park.

Several thousand visitors now enter the park each year, and by 2007 there were growing populations of almost all species. There is continued commitment from the Carr foundation and the Mozambique government to support the park and surrounding communities to employ their energy and creativity to continue rebuilding the region. Notwithstanding ongoing challenges, for a region that two decades ago emerged ravaged from a brutal civil war, this has been a tremendous success story.

This example illustrates how identification of a few key leverage points can provide the basic structure around which a destructured SES can start rapidly reorganizing in a selfreinforcing way. Such an approach can be very cost effective because rather than trying to directly rebuild individual components of a system, this strategy focuses on providing the critical "seeds" that enable the system to rebuild itself over time.

\section{Gacaca courts, Rwanda}

Rwanda made international headlines in 1994 for a genocide that claimed roughly 800,000 lives in a space of 100 days, making it perhaps the fastest genocide in history (Des Forges 1999). Although there are diverse views on what triggered the genocide, it is generally agreed that the violence stemmed from animosity between the Hutu and Tutsi that had built up for over a century and had its roots in the higher standing given to the Tutsi by the Belgian colonial administration (Rusagara 2005). The genocide left Rwanda reeling. The country had lost $10 \%$ of its population, many people had witnessed acts of extreme brutality, societal relations were extremely strained, and the country's infrastructure was in a state of disrepair, leading to near total state collapse (Prunier 1997). The dominant feedbacks that had previously created structure and order had been seriously weakened or lost, and the future of the country was highly uncertain.

A key challenge facing postgenocide Rwanda was repairing and rebuilding social trust because this was widely recognized as essential for catalyzing broader societal reconstruction and development, thus constituting a key leverage point. Central in this regard was to reconstitute an impartial justice system to prosecute those who had perpetrated and participated in the genocide. To assist with this effort the United Nations set up an International Criminal Tribunal for Rwanda (ICTR). However, it quickly became apparent that it would take the ICTR decades to deal with the 130,000 genocide suspects in prison (Prunier 1997). This put pressure on the Rwandan government to grant some form of blanket amnesty, but risked leading to a re-eruption of violence if people felt justice had not been served. To deal with this situation, the transitional Rwandan government came up with a key innovation: the establishment of traditional Gacaca courts throughout the country to prosecute everyone aside from the planners and ideologues, who were to be prosecuted by the ICTR.

Gacaca courts are traditional councils and tribunals made up of elders to resolve conflict and are based on principles of restorative justice. The system is communal and participatory, requiring that suspects be tried and judged by neighbors in their community (Fig. 4). The aim of the process was not simply to expose perpetrators of the genocide or to shame bystanders, but to help rebuild social trust through a locally driven, people-centered and people-owned approach (Rusagara 2005). The Gacaca courts are recognized as having played a key role in rebuilding social trust through a process of collectively determined justice, and enabling processes of social reconstruction to emerge at the grassroots level. In doing so, they weakened the social interactions and feedbacks that had led to the violence and set in motion the country's new nation-building ethos, exemplifying the African proverb "when you want to resolve disputes, you do not take a knife to cut, but a needle to sew" (Rusagara 2005). Although there have been continued occurrences of revenge and injustice as well as concerns about democratic freedoms (The Economist 2004), the postgenocide reconstruction of Rwanda was astounding, and is difficult to imagine without the self-reinforcing processes of reconciliation that the Gacaca courts enabled.

Fig. 4. Gacaca courts were mostly held outside on the grass. Photo credit: Samuel Gasana for PRI, Jeb Sharp for PRI, http://www.pri.org/stories/2007-02-14/part-ii-rwandas-gacacacourts.

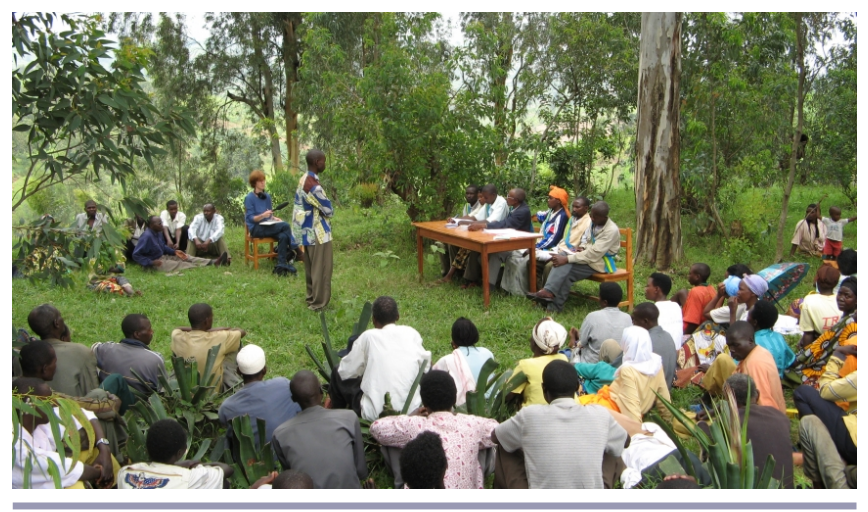

This example illustrates the power that systemic self-organizing processes can have in helping restructure and rebuild SES. In this case, national level laws sanctioning the Gacaca courts created the framework to catalyze self-organizing processes of reconstruction at the grass-roots level. These bottom-up processes then scaled up to interact with larger-scale processes to shape a positive development trajectory for the country. On the other hand, this example and experience elsewhere also suggests that in highly fractured situations, there is a substantial risk that destructive self-organizing processes take hold, such as the rise of regional militia or warlords.

\section{Strategy 4: set safe boundaries to avoid system thresholds}

Like many complex adaptive systems, SES can exist in several selforganizing states or regimes (Scheffer 2009, Levin et al. 2013). Shifts between regimes occur when a critical threshold is crossed that triggers a reorganization of the structure and dominant feedbacks in the system, typically leading to large, abrupt, nonlinear changes (Scheffer et al. 2001, Biggs et al. 2012a). Regime shifts, for example, the collapse of an important fishery, often have substantial impacts on human well-being and are expensive or impossible to reverse (MA 2005, Crépin et al. 2012). 
Predicting and avoiding regime shifts is, however, notoriously difficult. Regime shifts typically result from a stochastic shock, e.g., fire or flood, combined with slow changes in underlying variables that have driven the system close to a critical threshold (Biggs et al. 2012a). The critical levels of underlying variables that trigger regime shifts are almost always unknown, vary between different systems, and change over time in response to changes in key system variables (Scheffer 2009). Pinning down the precise level of key system thresholds in relation to specific underlying system variables is therefore extremely difficult, creating substantial uncertainty about if and when undesired regime shifts might occur.

Nevertheless, it is sometimes possible to estimate the approximate level of the threshold based on knowledge of the system or previous observations of regime shifts in similar SES (Scheffer and Carpenter 2003, Carpenter and Lathrop 2008). To account for the uncertainty surrounding suspected thresholds, one practical strategy is to set a "safe boundary" some distance from a suspected threshold (Fig 5). The distance from the threshold will depend on several factors, including uncertainty about the threshold, the potential consequences of crossing the threshold, the degree of risk aversion, and the inherent variability of the system (Carpenter 2003, Rockström et al. 2009). Importantly, once set, boundaries need to be revised and updated periodically in the light of new data and changes in key system variables that may affect the position of the threshold (Scheffer 2009). Below we present two examples where safe boundaries have been set to help manage SES and prevent the crossing of suspected thresholds.

Fig. 5. Setting safe boundaries is a common approach to dealing with system thresholds or tipping points. The distance between the boundary and the suspected system threshold will depend on factors such as the uncertainty about the threshold level, the consequences of crossing the threshold, and the inherent variability of the system.

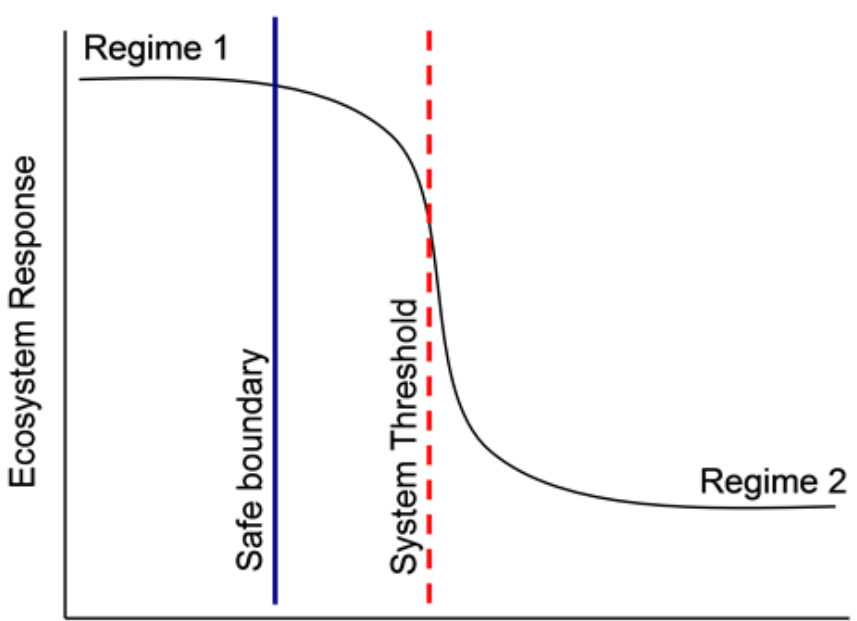

Ecosystem Driver/ Management Variable

\section{Thresholds of Potential Concern (TPCS), Kruger National Park, South Africa}

The thresholds of potential concern (TPC) approach developed in the Kruger National Park, South Africa provides an innovative model for attempting to set safe boundaries, and at the same time encourage learning about thresholds (Biggs and Rogers 2003). TPCs are a set of operational goals that together define the hypothesized boundaries of the social-ecological regime that park management aims to maintain to meet its objectives of biodiversity preservation and benefits to people (Roux and Foxcroft 2011). Operationally, TPCs are defined in terms of upper and lower levels of acceptable change in a selected set of environmental indicators. Each TPC represents a safe boundary, or "worry level," set some distance from a hypothesized system threshold in ecosystem structure, function, or composition (Rogers and Biggs 1999). For example, one TPC for fish assemblages is a decrease ( $>35 \%$ decline in number of localities collected in different surveys) in the distribution of an indigenous fish species that is permanently resident in a river.

In practice, the TPCs represent a mixture of "true" systems thresholds separating alternate regimes, e.g., open grassy savannas and closed wooded savannas, and value-based thresholds or limits of acceptable change in ecosystem conditions, e.g., the establishment of an alien species in the park that does not necessarily have a significant ecosystem impact. The information underlying the TPCs ranges from relatively well understood ecosystem dynamics, through informed expert opinion, to intelligent guesswork (Biggs et al. 2011, McLoughlin et al. 2011). Because all TPCs are framed as hypotheses, their validity and appropriateness are always open to challenge, with the intention that they should be adaptively modified and updated as understanding of the system grows (Rogers and Biggs 1999).

The TPCs also function as a key mechanism for linking science and management because they form an integral part of the strategic adaptive management system for the Kruger Park (Roux and Foxcroft 2011; see strategy 1). When monitoring indicates that the upper or lower level of a TPC has been reached, or modeling predicts such a level will soon be reached, it triggers a formal meeting of scientists and managers. At this meeting, a formal decision is required to implement a course of management action to moderate the system change, or alternatively to adjust the TPC to a new level in the light of new knowledge or understanding. By embedding the TPCs within a formal decisionmaking process, it ensures that there is a discreet point at which park managers are required to act upon monitoring information, something that seems obvious but often does not happen in practice (Biggs and Rogers 2003).

This example illustrates several key innovations in setting safe boundaries. First, it takes the idea of system thresholds as a starting assumption for ecosystem management rather than as an exception, and tries to proactively identify potential thresholds across a wide range of ecosystem components. Second, the approach enables the notion of system thresholds to be operationalized across a wide range of ecosystem parameters in an integrated, practical way. Third, by framing the TPCs as hypotheses, it encourages ongoing experimentation, learning, and adaptation of the boundaries. Finally, the TPC approach integrates the notion of ecosystem thresholds into an adaptive management approach that creates a formal link between science and management. The approach is now being taken up across other parks in the region as well as internationally, and has been incorporated as a tool in the Resilience Alliance Workbook (RA 2007). 


\section{Abalone management, South Africa}

Fisheries managers have long used indicators such as stock biomass and genetic diversity to assess stocks and calculate maximum sustainable yields. Based on these assessments, various boundaries, such as total allowable catch (TAC), are set to ensure the sustainability of the fishery (Walters and Martell 2004). However, there are numerous examples where despite such boundaries, fisheries have collapsed. This is often because the boundaries do not account for changes and uncertainties in the larger SES within which the fishery is embedded, which can mean that the safe boundary may have changed or have been inappropriately set (Finlayson and McCay 1998). The South African abalone (or perlemoen) is an example of a fishery that has suffered such unanticipated collapse.

Abalone are a large, edible sea snail that live in shallow coastal waters and are considered a delicacy in southern Africa, and are a major export to the Far East (Fig. 6). It is one of South Africa's oldest fisheries, and one of the most lucrative (Tarr 1992). Over time several boundaries have been set to protect the fishery from intense fishing pressure. The most important has been TAC per person based on estimates of stock size and catch per unit effort (CPUE). However, a major difficulty in setting TAC is that it cannot be based only on reproductive traits, but needs to account for the complex ecological and social context within which the fishery is embedded (Stergiou 2002). Abalone populations are known to vary significantly through time and space for various ecological reasons, such as increases in predators like rock lobster. More importantly, however, changes in the political and economic context of the fishery can lead to changes in harvesting behavior, i.e., CPUE, and, especially, the level of illegal poaching.

Fig. 6. Abalone are a highly sought-after large edible sea snail. Photo credit: Molecular Breeding \& Biodiversity Group, Department of Genetics, Stellenbosch University.

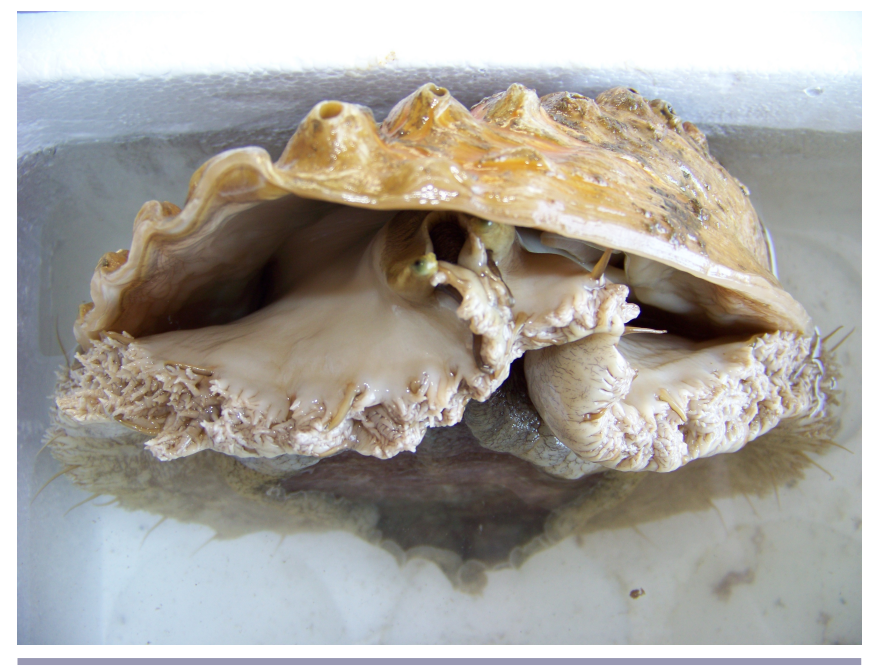

Such a situation arose in South Africa when the country opened up to global markets following the end of Apartheid, and abalone poaching suddenly became a major problem (Fig 6; Hauck and Sweijd 1999, Raemaèkers et al. 2011). Because the increased poaching was not immediately obvious, the legal TAC limits did not initially take the increased illegal offtake into account in their estimation of the fish stock size, and abalone started declining rapidly. TACs were subsequently repeatedly lowered in an effort to stabilize the fishery (Tarr 1992, Hauck and Sweijd 1999). By the early 2000s it became clear that these measures were failing to protect the abalone, and in 2008 the South African government completely closed the fishery as a last resort to protect declining populations. Enforcement measures to counteract poaching were failing and the TAC had clearly not been adjusted sufficiently or rapidly enough to ensure that the combined off-take through poaching and legal harvests did not exceed the reproduction rate of the abalone.

In an attempt to address the poaching problem, the government is in the process of developing a small-scale fishing policy that will allow local communities to utilize the fishery. It has been proposed that a system of individual custodianship, implemented through the allocation of long-term abalone fishing rights be implemented. This is possible because abalone is an intrinsically stationary species, clinging to a particular rock often in the exact same location for several years (Tarr 1992). In combination with an improved monitoring and enforcement system, and based on a growing body of experience in local-scale natural resource governance (Ostrom 1990, Armitage et al. 2007), it is expected that this system would provide the fishers with an incentive to manage the fishery more sustainably and to report and combat illegal harvesting. If the illegal harvests can be reduced to a relatively small level, it would then again be possible to set a legal TAC once the abalone population has recovered.

This example highlights an important pitfall in the setting of safe boundaries: if conditions in the larger SES change in a way that is not accounted for in the boundary, the system will be put at risk of a regime shift. Although this is an extreme example in which the level of poaching rose so rapidly and became so large that it became impossible to account for it in the TAC, a situation in which the previously determined safe boundary becomes unsafe because of changes in the larger SES can often arise. The example therefore underscores the need to constantly monitor changes in the larger SES that might affect the level of the safe boundary, to adjust boundaries over time in response to changes in the SES, and to provide some degree of buffer for unexpected changes and fluctuations when setting the safe boundary level.

\section{CONCLUSION}

The urgent sustainability challenges facing society, particularly in developing regions such as Sub-Saharan Africa, demand new and expanded frameworks and approaches for understanding and managing interconnected and interdependent social, economic, and ecological systems (Bammer 2005, MA 2005, Chapin et al. 2009). The developing body of literature on SES as complex adaptive systems emphasizes that strategies for managing SES in the face of substantive uncertainty will be central to our ability to engage with the sustainability challenges we face (Norberg and Cumming 2008, Carpenter et al. 2012, Levin et al. 2013). Drawing especially on the resilience literature, we have identified four such strategies: (1) employ adaptive management or comanagement, (2) engage and integrate different perspectives, (3) facilitate selforganization, and (4) set safe boundaries to avoid system thresholds. Using examples from South Africa and the broader southern and East African region, we have illustrated how each of these strategies has been applied in innovative, pragmatic ways to manage uncertain SES in a developing regional context. 
These strategies complement and expand on more conventional scientific approaches. The conventional scientific approach to addressing uncertainty in SES has been to conduct more research to better inform management. This approach is usually based on the assumption that further research will reduce uncertainty (Cortner and Moote 1999, Bocking 2004), or at least clarify levels of uncertainty (e.g., Scholes and Mennell 2008, Mastrandrea et al. 2010), and thereby clarify the most appropriate course of action. Furthermore, it is often implicitly assumed that until there is sufficient certainty to substantiate a change in management, the best option is to maintain existing management actions, based on the implicit notion that maintaining current actions will maintain the current condition of the SES. However, in the context of complex adaptive SES, particularly under conditions of rapid change, "freezing" an SES in particular condition is almost impossible. Instead, decisions to continue versus change current management actions entails a choice between different potential trajectories of SES change, all of which typically entail substantial uncertainties and will likely lead to very different outcomes than the present SES condition (Holling 2001). Conventional scientific approaches can make an important contribution to understanding these different potential trajectories and outcomes. At the same time the four strategies discussed here can facilitate and enable ongoing management and learning in the face of sometimes overwhelming uncertainty about which choice is best.

The four strategies we identified were based on a review of the resilience literature and our knowledge of different socialecological cases in the southern African region. Formulated at this generic level, the four strategies represent many aspects of the resilience literature; however, additional strategies and other formulations or finer level subdivisions of the strategies are clearly possible. For example, Biggs et al. (2012b, 2015) identified seven underlying principles for building resilience. In accordance with our understanding of complexity, rather than being a source of confusion, different formulations of underlying principles and strategies for managing SES provide different ways of interrogating and understanding these systems. In doing so, they most likely broaden our perspective, deepen our insights, and increase our problem-solving capacity (Hong and Page 2004, Biggs et al. 2009). Although we focused specifically on strategies that are appropriate in the context of southern Africa, a fast developing region, the strategies appear highly applicable also in developed regions (Gunderson et al. 1995, Olsson et al. 2006, Walker and Salt 2006). Furthermore, although some of the examples discussed in this paper were inspired by the resilience literature, many of the cases were not, highlighting the extent to which innovative approaches that can be understood through a resilience lens are emerging from a variety of research fields.

The examples in this paper suggest that the nature of a particular problem and its social-ecological context (e.g., variety of stakeholders and their learning preferences, level of uncertainty), will determine which strategy, or mix of strategies is most appropriate in a particular situation. All four strategies to some extent address issues of analytical, ontological, and societal complexity arising from different sources of uncertainty in SES. However, most of the strategies are more targeted toward one of these aspects of complexity than others (Fig. 1), which can help in guiding choices about the relative emphasis to place on different strategies in particular contexts. At the same time it is critical to keep in mind that none of the strategies are sufficient in themselves and need to be integrated into an overall response. Interestingly, our examples highlight the importance of social trust in all the strategies, suggesting that this is a key feature necessary for decision making in the face of uncertainty. As illustrated by the examples in this paper, each of the strategies can be applied in different ways, using a diversity of tools and approaches (Fig. 1). In many cases, however, the specific choice of strategies may matter less than that some set is decided and acted upon in a way that takes account of diverse stakeholder interests and builds and maintains trust.

The examples we have provided indicate that it is possible, even under the challenging conditions facing developing regions, to apply these four strategies in pragmatic ways that can make a real difference on the ground and foster more sustainable trajectories of change. What's more, our examples indicate that the pressures facing developing regions and their differing cultural contexts can sometimes lead to highly innovative ways of applying these strategies, such as the Gacaca courts in Rwanda, or the Threshold of Potential Concern (TPC) approach in the Kruger National Park. One of our key aims has been to contribute a new set of examples, specifically from the southern and East African region, to complement the existing repertoire of case studies in the resilience literature. Taken together with existing examples, these case studies provide some optimism that the strategies discussed can be practically applied in highly complex, uncertain, and contentious situations to help address the enormous sustainability challenges facing society in the 21 st century.

\section{Responses to this article can be read online at: http://www.ecologyandsociety.org/issues/responses. $\mathrm{php} / 7380$}

\begin{abstract}
Acknowledgments:
The development of this paper was made possible through the Akili Complexity and Integration Initiative, funded by the South African National Research Foundation. Reinette Biggs's participation in and coordination of the Akili Young Scientists group was made possible through the support of a Society in Science Branco Weiss Fellowship and a fellowship at the Stellenbosch Institute for Advanced Study (STIAS). We thank Bernelle Verster for her contribution to the early stages of the paper, and Harry Biggs, Luthando Dziba, Cecile Gerwel, Johann Lanz, and Sydney Mavengahama for helpful comments on the draft manuscript. We also particularly thank the three external reviewers and the subject editor for their helpful suggestions and comments which substantially strengthened the paper.
\end{abstract}

\section{LITERATURE CITED}

Alcamo, J. 2001. Scenarios as tools for international environmental assessments. European Environmental Agency, Luxembourg.

Allan, C., and G. H. Stankey, editors. 2009. Adaptive environmental management: a practitioner's guide. Springer, Dordrecht, Netherlands. http://dx.doi.org/10.1007/978-1-4020-9632-7 
Allenby, B., and D. Sarewitz. 2011. The techno-human condition. MIT Press, Cambridge, Massachusetts, USA.

Armitage, D., F. Berkes, and N. Doubleday, editors. 2007. Adaptive co-management: collaboration, learning, and multi-level governance. University of British Columbia Press, Vancouver, British Columbia, Canada.

Armitage, D. R., R. Plummer, F. Berkes, R. I. Arthur, A. T. Charles, I. J. Davidson-Hunt, A. P. Diduck, N. C. Doubleday, D. S. Johnson, M. Marschke, P. McConney, E. W. Pinkerton, and E. K. Wollenberg. 2009. Adaptive co-management for socialecological complexity. Frontiers in Ecology and the Environment 7:95-102. http://dx.doi.org/10.1890/070089

Audouin, M., R. Preiser, S. Nienaber, L. Downsborough, J. Lanz, and S. Mavengahama. 2013. Exploring the implications of critical complexity for the study of social-ecological systems. Ecology and Society 18(3): 12. http://dx.doi.org/10.5751/ES-05434-180312

Bammer, G. 2005. Integration and implementation sciences: building a new specialization. Ecology and Society 10(2): 6. [online] URL: http://www.ecologyandsociety.org/vol10/iss2/ art6l

Berkes, F., J. Colding, and C. Folke, editors. 2003. Navigating social-ecological systems: building resilience for complexity and change. Cambridge University Press, Cambridge, UK. http://dx. doi.org/10.1017/CBO9780511541957

Biggs, H., S. Ferreira, S. Freitag-Ronaldson, and R. Grant-Biggs. 2011. Taking stock after a decade: Does the 'Thresholds of Potential Concern' concept need a socio-ecological revamp? Koedoe 53:66-74. http://dx.doi.org/10.4102/koedoe.v53i2.1002

Biggs, H. C., and K. H. Rogers. 2003. An adaptive system to link science, monitoring, and management in practice. Pages 59-80 in J. T. du Toit, K. H. Rogers, and H. C. Biggs, editors. The Kruger experience: ecology and management of savanna heterogeneity. Island Press, Washington, D.C., USA.

Biggs, R., T. Blenckner, C. Folke, L. J. Gordon, A. Norström, M. Nyström, and G. D. Peterson. 2012a. Regime shifts. Pages 609-616 in A. Hastings and L. J. Gross, editors. Encyclopedia of theoretical ecology. University of California Press, Berkeley, California, USA.

Biggs, R., S. R. Carpenter, and W. A. Brock. 2009. Spurious certainty: how ignoring measurement error and environmental heterogeneity may contribute to environmental controversies. BioScience 59:65-76. http://dx.doi.org/10.1525/bio.2009.59.1.10

Biggs, R., M. W. Diebel, D. Gilroy, A. M. Kamarainen, M. S. Kornis, N. D. Preston, J. E. Schmitz, C. K. Uejio, M. C. Van De Bogert, B. C. Weidel, P. C. West, D. P. Zaks, and S. R. Carpenter. 2010a. Preparing for the future: teaching scenario planning at the graduate level. Frontiers in Ecology and the Environment 8:267-273. http://dx.doi.org/10.1890/080075

Biggs, R., M. Schlüter, D. Biggs, E. L. Bohensky, S. BurnSilver, G. Cundill, V. Dakos, T. M. Daw, L. S. Evans, K. Kotschy, A. M. Leitch, C. Meek, A. Quinlan, C. Raudsepp-Hearne, M. D. Robards, M. L. Schoon, L. Schultz, and P. C. West. $2012 b$. Towards principles for enhancing the resilience of ecosystem services. Annual Review of Environment and Resources 37:421-448. http://dx.doi.org/10.1146/annurev-environ-051211-123836
Biggs, R., M. Schlüter, and M. L. Schoon, editors. 2015. Principles for building resilience: sustaining ecosystem services in socialecological systems. Cambridge University Press, Cambridge, UK.

Biggs, R., F. R. Westley, and S. R. Carpenter. 2010b. Navigating the back loop: fostering social innovation and transformation in ecosystem management. Ecology and Society 15(2): 9. [online] URL: http://www.ecologyandsociety.org/vol15/iss2/art9/

Bocking, S. 2004. Nature's experts: science, politics, and the environment. Rutgers University Press, New Brunswick, New Jersey, USA.

Brugnach, M., A. Tagg, F. Keil, and W. de Lange. 2007. Uncertainty matters: computer models at the science-policy interface. Water Resources Management 21:1075-1090. http://dx. doi.org/10.1007/s11269-006-9099-y

Burns, D. 2007. Systemic action research: a strategy for whole system change. Policy Press, Bristol, UK.

Carpenter, S. R. 2003. Regime shifts in lake ecosystems: pattern and variation. International Ecology Institute, Oldendorf/Luhe, Germany.

Carpenter, S. R., K. J. Arrow, S. Barrett, R. Biggs, W. A. Brock, A.-S. Crépin, G. Engström, C. Folke, T. P. Hughes, N. Kautsky, C.-Z. Li, G. McCarney, K. Meng, K.-G. Mäler, S. Polasky, M. Scheffer, J. Shogren, T. Sterner, J. R. Vincent, B. Walker, A. Xepapadeas, and A. de Zeeuw. 2012. General resilience to cope with extreme events. Sustainability 4:3248-3259. http://dx.doi. org/10.3390/su4123248

Carpenter, S. R., and R. C. Lathrop. 2008. Probabilistic estimate of a threshold for eutrophication. Ecosystems 11:601-613. http:// dx.doi.org/10.1007/s10021-008-9145-0

Chapin, F. S., G. P. Kofinas and C. Folke, editors. 2009. Principles of ecosystem stewardship: resilience-based natural resource management in a changing world. Springer, New York, New York, USA.

Cilliers, P. 1998. Complexity and postmodernism: understanding complex systems. Routledge, London, UK.

Cilliers, P., H. C. Biggs, S. Blignaut, A. G. Choles, J. S. Hofmeyr, G. P. W. Jewitt, and D. J. Roux. 2013. Complexity, modeling and natural resource management. Ecology and Society 18(3): 1. http://dx.doi.org/10.5751/ES-05382-180301

Clark, N. L., and W. H. Worger. 2011. South Africa: the rise and fall of apartheid. Routledge, London, UK.

Cortner, H. J., and M. A. Moote. 1999. The politics of ecosystem management. Island Press, Washington, D.C., USA.

Council for Scientific and Industrial Research (CSIR). 2001. State of the rivers report: crocodile, Sabie-sand \& Olifants River systems. CSIR, Pretoria, South Africa.

Crépin, A. S., R. Biggs, S. Polasky, M. Troell, and A. de Zeeuw. 2012. Regime shifts and management. Ecological Economics 84:15-22. http://dx.doi.org/10.1016/j.ecolecon.2012.09.003

Des Forges, A. L. 1999. Leave none to tell the story: genocide in Rwanda. Human Rights Watch, New York, New York, USA. 
Feltz, B., M. Crommelinck, and P. Goujon, editors. 2006. Selforganization and emergence in life sciences. Springer, Dordracht, Nethlerlands. http://dx.doi.org/10.1007/1-4020-3917-4

Finlayson, A. C., and B. J. McCay. 1998. Crossing the threshold of ecosystem resilience: the commercial extinction of northern cod. Pages 311-337 in F. Berkes and C. Folke, editors. Linking social and ecological systems: management practices and social mechanisms for building resilience. Cambridge University Press, Cambridge, UK.

Folke, C., S. R. Carpenter, B. Walker, M. Scheffer, T. Chapin, and J. Rockström. 2010. Resilience thinking: integrating resilience, adaptability and transformability. Ecology and Society 15(4): 20. [online] URL: http://www.ecologyandsociety.org/vol15/iss4/ art20/

Funtowicz, S. O., J. Martinez-Alier, G. Munda, and J. R. Ravetz. 1999. Information tools for environmental policy under conditions of complexity. European Environmental Agency, Luxembourg.

Gorongosa National Park. 2015. Timeline. Gorongosa National Park, Sofala, Mozambique. [online] URL: http://www. gorongosa.org/our-story/timeline

Gowlland-Gualtieri, A. 2010. South Africa's water law and policy framework: implications for the right to water. Pages 388-414 in $\mathrm{P}$. Cullet, A. Gowlland-Gualtieri, R. Madhav, and U. Ramanathan, editors. Water ggovernance in motion: towards socially and environmentally sustainable water laws. Foundation Books, Delhi, India. http://dx.doi.org/10.1017/UPO9788175968578.015

Griggs, D., M. Stafford-Smith, O. Gaffney, J. Rockström, M. C. Öhman, P. Shyamsundar, W. Steffen, G. Glaser, N. Kanie, and I. Noble. 2013. Policy: sustainable development goals for people and planet. Nature 495:305-307. http://dx.doi.org/10.1038/495305a

Gros, C. 2008. Complex and adaptive dynamical systems: a primer. Springer-Verlag, Berlin, Germany. http://dx.doi. org/10.1007/978-3-540-71874-1

Gunderson, L. H., and C. S. Holling, editors. 2002. Panarchy: understanding transformations in human and natural systems. Island Press, Washington, D.C., USA.

Gunderson, L. H., C. S. Holling, and S. S. Light. 1995. Barriers and bridges to the renewal of ecosystems and institutions. Columbia University Press, New York, New York, USA.

Gunderson, L. H., and L. Pritchard, editors. 2002. Resilience and the behavior of large-scale systems. Island Press, Washington, D. C., USA.

Harris, J., G. Branch, C. Sibiya and C. Bill. 2003. The Sokhulu subsistence mussel harvesting project: co-management in action. Pages 61-98 in M. Hauck and M. Sowman, editors. Waves of change: coastal and fisheries co-management in South Africa. University of Cape Town Press, Lansdowne, South Africa.

Hatton, J., M. Couto, and J. Oglethorpe. 2001. Biodiversity and war: a case study of Mozambique. Biodiversity Support Program, Washington, D.C., USA.

Hauck, M., and N. A. Sweijd. 1999. A case study of abalone poaching in South Africa and its impact on fisheries management. ICES Journal of Marine Science 56:1024-1032. http://dx.doi. org/10.1006/jmsc.1999.0534
Herrfahrdt-Pähle, E. 2010. South African water governance between administrative and hydrological boundaries. Climate and Development 2:111-127. http://dx.doi.org/10.3763/cdev.2010.0038

Holland, J. H. 1999. Emergence: from chaos to order. Basic Books, New York, New York, USA.

Holling, C. S., editor. 1978. Adaptive environmental assessment and management. John Wiley, New York, New York, USA.

Holling, C. S. 2001. Understanding the complexity of economic, ecological, and social systems. Ecosystems 4:390-405. http://dx. doi.org/10.1007/s10021-001-0101-5

Holling, C. S., and G. K. Meffe. 1996. Command and control and the pathology of natural resource management. Conservation Biology 10:328-337. http://dx.doi.org/10.1046/j.1523-1739.1996.10020328. $\underline{x}$

Hong, L., and S. E. Page. 2004. Groups of diverse problem solvers can outperform groups of high-ability problem solvers. Proceedings of the National Academy of Sciences 101:16385-16389. http://dx.doi.org/10.1073/pnas.0403723101

Kahane, A. 1992. The Mont Fleur scenarios: What will South Africa be like in the year 2002? Deeper News 7:1-22.

Kahane, A. 2004. Solving tough problems: an open way of talking, listening, and creating new realities. Berrett-Koehler, San Francisco, California, USA.

Kahane, A. 2010. Power and love: a theory and practice of social change. Berrett-Koehler, San Francisco, California, USA.

Kates, R. W., W. C. Clark, R. Corell, J. M. Hall, C. C. Jaeger, I. Lowe, J. J. McCarthy, H. J. Schellnhuber, B. Bolin, N. M. Dickson, S. Faucheux, G. C. Gallopín, A. Grübler, B. Huntley, J. Jäger, N. S. Jodha, R. E. Kasperson, A. Mabogunje, P. A. Matson, H. Mooney, B. Moore III, T. O'Riordan, and U. Svedin. 2001. Sustainability science. Science 292:641-642. http://dx.doi. org/10.1126/science.1059386

Leach, A., G. Cundill, L. Schultz, and C. L. Meek. 2015. Principle 6: broaden participation. Pages 201-225 in R. Biggs, M. Schlüter, and M. L. Schoon, editors. Principles for building resilience: sustaining ecosystem services in social-ecological systems. Cambridge University Press, Cambridge, UK.

Lee, K. N. 1993. Appraising adaptive management. Conservation Ecology 3(2): 3. [online] URL: http://www.consecol.org/vol3/iss2/ $\underline{\operatorname{art} 3 /}$

Levin, S., T. Xepapadeas, A. S. Crépin, J. Norberg, A. de Zeeuw, C. Folke, T. Hughes, K. Arrow, S. Barrett, G. Daily, P. Ehrlich, N. Kautsky, K. G. Mäler, S. Polasky, M. Troell, J. R. Vincent, and B. Walker. 2013. Social-ecological systems as complex adaptive systems: modeling and policy implications. Environment and Development Economics 18:111-132. http://dx.doi.org/10.1017/ $\underline{\mathrm{S} 1355770 \mathrm{X} 12000460}$

Martin, J. 2007. The meaning of the 21st century: a vital blueprint for ensuring our future. Riverhead Books, New York, New York, USA.

Mastrandrea, M. D., C. B. Field, T. F. Stocker, O. Edenhofer, K. L. Ebi, D. J. Frame, H. Held, E. Kriegler, K. J. Mach, P. R. Matschoss, G.-K. Plattner, G. W. Yohe, and F. W. Zwiers. 2010. Guidance note for lead authors of the IPCC Fifth Assessment 
Report on consistent treatment of uncertainties. Intergovernmental Panel on Climate Change, Geneva, Switzerland.

McKay, J., and P. Marshall. 2001. The dual imperatives of action research. Information Technology \& People 14:46-59. http://dx. doi.org/10.1108/09593840110384771

McLoughlin, C. A., A. Deacon, H. Sithole, and T. Gyedu-Ababio. 2011. History, rationale, and lessons learned: thresholds of potential concern in Kruger National Park river adaptive management. Koedoe 53:75-101. http://dx.doi.org/10.4102/ koedoe.v53i2.996

Meadows, D. H. 2008. Thinking in systems: a primer. Chelsea Green, White River Junction, Vermont, USA.

Millennium Ecosystem Assessment (MA). 2005. Ecosystems and human well-being: synthesis. Island Press, Washington, D.C., USA.

Mollinga, P. P. 2010. Boundary work and the complexity of natural resources management. Crop Science 50:S1-S9.

Norberg, J., and G. S. Cumming, editors. 2008. Complexity theory for a sustainable future. Columbia University Press, New York, New York, USA.

Nyström, M., A. Norström, T. Blenckner, M. de la Torre-Castro, J. Eklöf, C. Folke, H. Österblom, R. S. Steneck, M. Thyresson, and M. Troell. 2012. Confronting feedbacks of degraded marine ecosystems. Ecosystems 15:695-710. http://dx.doi.org/10.1007/ $\underline{\text { s10021-012-9530-6 }}$

O'Keeffe, J., and K. H. Rogers. 2003. Heterogeneity and management of the Lowveld rivers. Pages 447-468 in J. T. du Toit, K. H. Rogers and H. C. Biggs, editors. The Kruger experience: ecology and management of savanna heterogeneity. Island Press, Washington, D.C., USA.

Olsson, P., L. H. Gunderson, S. R. Carpenter, P. Ryan, L. Lebel, C. Folke, and C. S. Holling. 2006. Shooting the rapids: navigating transitions to adaptive governance of social-ecological systems. Ecology and Society 11(1): 18. [online] URL: http://www. ecologyandsociety.org/vol11/iss1/art18/

Ostrom, E. 1990. Governing the commons: the evolution of institutions for collective action. Cambridge University Press, New York, New York, USA. http://dx.doi.org/10.1017/CBO9780511807763

Ostrom, E. 2005. Understanding institutional diversity. Princeton University Press, Princeton, New Jersey, USA.

Ostrom, E. 2007. A diagnostic approach for going beyond panaceas. Proceedings of the National Academy of Sciences 104:15181-15187. http://dx.doi.org/10.1073/pnas.0702288104

Ostrom, E., M. A. Janssen, and J. M. Anderies. 2007. Going beyond panaceas. Proceedings of the National Academy of Sciences 104:15176-15178. http://dx.doi.org/10.1073/pnas.0701886104

Parsons, K., editor. 2003. The science wars: debating scientific knowledge and technology. Prometheus Books, Amherst, New York, USA.

Peterson, G. D., G. S. Cumming, and S. R. Carpenter. 2003. Scenario planning: a tool for conservation in an uncertain world. Conservation Biology 17:358-366. http://dx.doi.org/10.1046/ j.1523-1739.2003.01491.x
Postel, S., and B. Richter. 2003. Rivers for life: managing water for people and nature. Island Press, Washington, D.C., USA.

Prunier, G. 1997. The Rwanda crisis: history of a genocide. Columbia University Press, New York, New York, USA.

Raemaèkers, S., M. Hauck, M. Bürgener, A. Mackenzie, G. Maharaj, É. E. Plagányi, and P. J. Britz. 2011. Review of the causes of the rise of the illegal South African abalone fishery and consequent closure of the rights-based fishery. Ocean \& Coastal Management 54:433-445. http://dx.doi.org/10.1016/j. ocecoaman.2011.02.001

Reason, P., and H. Bradbury. 2007. The SAGE handbook of action research: participative inquiry and practice. SAGE, London, UK.

Resilience Alliance (RA). 2007. Assessing and managing resilience in social-ecological systems: A practitioners workbook.

Robinson, D. A. 2006. Curse on the land: a history of the Mozambican civil war. Dissertation, University of Western Australia, Perth, Australia. [online] URL: http://researchrepository.uwa.edu.au/en/publications/curse-on-the-land-a-historyof-the-mozambican-civil-war\%288f29f45e-9b89-4327-93ac-25643cba7908\%29/export.html

Rockström, J., W. Steffen, K. Noone, Å. Persson, F. S. Chapin III, E. F. Lambin, T. M. Lenton, M. Scheffer, C. Folke, H. J. Schellnhuber, B. Nykvist, C. A. de Wit, T. Hughes, S. van der Leeuw, H. Rodhe, S. Sörlin, P. K. Snyder, R. Constanza, U. Svedin, M. Falkenmark, L. Karlberg, R. W. Correll, V. J. Fabry, J. Hansen, B. Walker, D. Liverman, K. Richardson, P. Crutzen, and J. A. Foley. 2009. A safe operating space for humanity. Nature 461:472-475. http://dx.doi.org/10.1038/461472a

Rogers, K., and H. C. Biggs. 1999. Integrating indicators, endpoint and value systems in the strategic management of the rivers of the Kruger National Park. Freshwater Biology 41:439-451. http://dx.doi.org/10.1046/j.1365-2427.1999.00441.x

Rogers, K. H., D. J. Roux, and H. C. Biggs. 2000. Challenges for catchment management agencies: lessons from bureaucracies, business and resource management. Water SA 26:505-511.

Roux, D. J., and L. C. Foxcroft. 2011. The development and application of strategic adaptive management within South African National Parks. Koedoe 53:1-5. http://dx.doi. org/10.4102/koedoe.v53i2.1049

Rusagara, F. K. 2005. Gacaca as a reconciliation and nationbuilding strategy in Rwanda. Conflict Trends 2005:20-29.

Scheffer, M. 2009. Critical transitions in nature and society. Princeton University Press, Princeton, New Jersey, USA.

Scheffer, M., and S. R. Carpenter. 2003. Catastrophic regime shifts in ecosystems: linking theory to observation. Trends in Ecology and Evolution 18:648-656.

Scheffer, M., S. R. Carpenter, J. A. Foley, C. Folke, and B. H. Walker. 2001. Catastrophic shifts in ecosystems. Nature 413:591-596. http://dx.doi.org/10.1038/35098000

Scholes, R. J., and K. G. Mennell, editors. 2008. Elephant management: a scientific assessment for South Africa. University of the Witwatersrand Press, Johannesburg, South Africa. 
Stafford Smith, M., L. Horrocks, A. Harvey, and C. Hamilton. 2011. Rethinking adaptation for a $4^{\circ} \mathrm{C}$ world. Philosophical Transactions of the Royal Society A: Mathematical, Physical and Engineering Sciences 369:196-216. http://dx.doi.org/10.1098/ $\underline{\text { rsta.2010.0277 }}$

Stergiou, K. I. 2002. Overfishing, tropicalization of fish stocks, uncertainty and ecosystem management: resharpening Ockham's razor. Fisheries Research 55:1-9. http://dx.doi.org/10.1016/ $\underline{\mathrm{S} 0165-7836(01) 00279-\mathrm{X}}$

Swart, R., L. Bernstein, M. Ha-Duong, and A. Petersen. 2009. Agreeing to disagree: uncertainty management in assessing climate change, impacts and responses by the IPCC. Climatic Change 92:1-29. http://dx.doi.org/10.1007/s10584-008-9444-7

Tarr, R. J. Q. 1992. The abalone fishery of South Africa. Pages 438-447 in S. A. Shepherd, M. J. Tegner, and S. A. Guzmán del Próo, editors. Abalone of the world. Fishing News Books, Cambridge, UK.

The Economist. 2004. Rwanda since the genocide: the road out of hell. 25 March. [online] URL: http://www.economist.com/ node/2535789

United Nations Development Programme (UNDP). 2013. Human development report 2013. The rise of the south: human progress in a diverse world. UNDP, New York, New York, USA.

United Nations Development Programme, United Nations Environment Programme, World Bank, and World Resources Institute (UNDP, UNEP, WB, and WRI). 2003. Mind over mussels: rethinking Mapelane Nature Reserve. Pages 174-181 in World Resources 2002-2004. World Resources Institute, Washington, D.C., USA. [online] URL: http://www.wri.org/ publication/world-resources-2002-2004

United Nations Environment Programme (UNEP). 2006. Protecting the coastal and marine environment from impacts of land-based activities: a guide for national action. UNEP-GPA, The Hague, Netherlands.

van Wilgen, B. W., H. C. Biggs, S. O'Regan, and N. Mare. 2000. A fire history of the savanna ecosystems in the Kruger National Park, South Africa between 1941 and 1996. South African Journal of Science 96:167-178.

van Wilgen, B. W., N. Govender, G. G. Forsyth, and T. Kraaij. 2011. Towards adaptive fire management for biodiversity conservation: experience in South African National Parks. Koedoe 53:Art \#982 http://dx.doi.org/10.4102/koedoe.v54i1.982

Venter, F. J., and A. R. Deacon. 1995. Managing rivers for conservation and ecotourism in the Kruger National Park. Water Science and Technology 32:227-233. http://dx.doi.org/10.1016/0273-1223 (95)00667-2

Walker, B., and D. Salt. 2006. Resilience thinking: sustaining ecosystems and people in a changing world. Island Press, Washington, D.C., USA.

Walker, B., and D. Salt. 2012. Resilience practice: building capacity to absorb disturbance and maintain function. Springer, Dordrecht, Netherlands. http://dx.doi.org/10.5822/978-1-61091-231-0
Walters, C. J. 1986. Adaptive management of renewable resources. Macmillan, New York, New York, USA.

Walters, C. J., and C. S. Holling. 1990. Large-scale management experiments and learning by doing. Ecology 71:2060-2068. http:// dx.doi.org/10.2307/1938620

Walters, C. J., and S. J. D. Martell. 2004. Fisheries ecology and management. Princeton University Press, Princeton, New Jersey, USA.

Westley, F. R., B. Zimmerman, and M. Q. Patton. 2006. Getting to maybe: how the world is changed. Vintage Canada, Toronto, Ontario, Canada.

Wondolleck, J. M., and S. L. Yaffee. 2000. Making collaboration work: lessons from innovation in natural resource management. Island Press, Washington, D.C., USA.

Young, O. R. 2010. Institutional dynamics: resilience, vulnerability and adaptation in environmental and resource regimes. Global Environmental Change 20:378-385. http://dx.doi. org/10.1016/j.gloenvcha.2009.10.001 